\title{
Cannibalism among size classes of larvae may be a substantial mortality component in tuna
}

\author{
P. Reglero ${ }^{1, *}$, A. Urtizberea ${ }^{2}$, A. P. Torres ${ }^{1}$, F. Alemany ${ }^{1}$, Ø. Fiksen ${ }^{2,3}$ \\ ${ }^{1}$ Instituto Español de Oceanografía, Centre Oceanogràfic de les Balears, Moll de Ponent s/n, 07015 Palma, Spain \\ ${ }^{2}$ Department of Biology, University of Bergen, PO Box 7803, 5020 Bergen, Norway \\ ${ }^{3}$ Uni Research, PO Box 7810, 5020 Bergen, Norway
}

\begin{abstract}
Cannibalism among size classes may reduce starvation and improve survival of larval tuna in oligotrophic ocean areas, but it may also be a substantial mortality component depending on the availability of alternative prey. Here, we combine laboratory and field data on tuna larvae with a model of larval foraging and bioenergetics to explore the role of cannibalism in cohort development at different temperatures, durations of hatching period, hatching larval densities and natural mortality rates. Prey fields (zooplankton densities and co-occurrence of different larval stages of 3 species of tuna) were established from cruises in a main tuna spawning area around the Balearic Islands (Mediterranean Sea). Results suggest that a pure zooplankton diet is frequently insufficient to sustain larval growth. Piscivory can be a major source of larval mortality among tuna species and larvae hatched early can feed on abundant larvae of smaller size and have fewer predators themselves. We show how the intensity of cannibalism depends on the temperature dependent growth rate and the resulting relative size distribution when eggs are released continuously over a period of a few weeks. The predator-prey size distribution and the relative densities of these voracious larvae may produce overcompensation in recruitment under some environmental conditions.
\end{abstract}

KEY WORDS: Cannibalism - Foraging model - Intraspecific predation - Natural mortality . Pelagic larvae $\cdot$ Predator-prey interactions $\cdot$ Size spectra $\cdot$ Surf-riding

Resale or republication not permitted without written consent of the publisher

\section{INTRODUCTION}

Cannibalism evolves in environments with low food availability (Folkvord 1997, Nishimura \& Hoshino 1999). In environments with high starvation risk for offspring, mothers may benefit from sacrificing some offspring as a food resource to others (Perry \& Roitberg 2006), and sometimes facilitate sibling cannibalism by asynchronic egg production (Polis 1981, Perry \& Roitberg 2005). When consecutive cohorts of different size coexist, piscivory and cannibalism depend on interactions between size classes and the ontogenetic size variations in both larval predator and larval prey (Persson \& De Roos 2006). The match or predator-prey overlap needs to include progressive changes in body size which Pope et al. (1994) termed 'surf-riding on the [size-spectrum] wave'. In other words, the key to success for a larva is 'being the right size at the right time' (Pope et al. 1994, p. 42).
Many large pelagic fish species, such as tuna and marlins, perform long spawning migrations. These species exploit very diverse environments, even subpolar seas, and tolerate a wide range of temperatures (Block et al. 2005). They generally spawn in oligotrophic areas where the abundance of plankton prey is often low. Their diet shifts from a more zooplankton-oriented to a piscivorous and even cannibalistic diet already during the early larval stages (Uotani et al. 1990, Young \& Davis 1990, Miyashita et al. 2001, Catalán et al. 2007, Morote et al. 2008). To become a piscivore, the larvae need to have large mouth gapes (Ottera \& Folkvord 1993, Folkvord et al. 1994, Nishimura \& Hoshino 1999), and to develop their digestive (Kaji et al. 1996) and visual systems rapidly (Margulies 1997). In fact, the large mouth gape in tuna larvae has been suggested as an adaptive morphological characteristic for a cannibal in the oligo- 
trophic pelagic environment (Nishimura \& Hoshino 1999). The intensity of piscivory and cannibalistic interactions also depends strongly on the size ratio between predators and prey (Claessen et al. 2000, Juanes et al. 2002).

Here we explore the role of cannibalism and piscivory in the growth and survival of the early developmental stages of tuna of different species. First, we obtained field estimates of zooplankton abundance and spatial coexistence of different tuna larval sizes. The study site is located around the Balearic Islands in the NW Mediterranean Sea, which is a main spawning site worldwide for bluefin tuna and other large pelagic fish species (Alemany et al. 2006, 2010). The 3 most abundant species of tuna are considered in this study: bluefin Thunnus thynnus (BFT), albacore Thunnus alalunga (ALB) and bullet tuna Auxis rochei (BT). Secondly, we developed 2 foraging models to (1) assess planktivory in tuna larvae and (2) model cannibalism/ piscivory as a size dependent interaction among tuna larvae where earlier born larvae may surf-ride the size spectra of the rest of the cohort or other larval tuna species (Pope et al. 1994). The model parameters were estimated using data for tuna and other species as available. Environmental ranges were set according to realistic scenarios from the field data on the spatial distribution of different species of tuna larvae and the mesozooplankton biomass. Finally, model simulations were used to estimate the impact of cannibalism and piscivory relative to temperature, hatching period, larval hatching densities and size dependent natural mortality rates.

\section{MATERIALS AND METHODS}

Field observations. Zooplankton biomass concentrations experienced by the larvae were estimated during summer 2004 and 2005 when fish larvae and mesozooplankton were collected around the Balearic Islands $\left(38^{\circ}\right.$ to $40.3^{\circ} \mathrm{N}, 1$ to $5^{\circ} \mathrm{E}$ ) using 333 and $200 \mu \mathrm{m}$ meshes fitted to Bongo nets (60 cm mouth opening) and equipped with flowmeters (General oceanics 230). Oblique tows were performed down to $70 \mathrm{~m}$ in the open sea or down to $5 \mathrm{~m}$ above the sea floor in shallower areas. The larvae were sampled at surface temperatures of $\sim 23.5^{\circ} \mathrm{C}$. The samples from the $200 \mu \mathrm{m}$ net were frozen at $-20^{\circ} \mathrm{C}$ and used to obtain mesozoo-

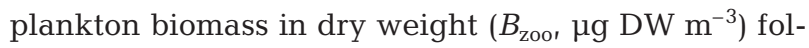
lowing Lovegrove (1966). Samples from the $333 \mu \mathrm{m}$ net were fixed with $4 \%$ formalin buffered with borax and the larvae of the tuna species further identified in the laboratory. The larvae of the 3 selected species were measured in standard length (SL, mm) and classified into 4 life stages according to morphological aspects and length intervals: yolk sac larvae (up to $3 \mathrm{~mm}$ ), preflexion (3 to $4.5 \mathrm{~mm}$ ), flexion ( 4.5 to $6 \mathrm{~mm}$ ) and postflexion (6 to $12 \mathrm{~mm}$ ), with no correction for shrinkage in formalin. The larvae were merged into 2 stages: Stage 1 larvae including yolk sac and preflexion developmental stages (BT1, ALB1 and BFT1 for bullet, albacore and bluefin tuna, respectively) and Stage 2 larvae including flexion and postflexion stages (BT2, ALB2 and BFT2, respectively). We estimated the average mesozooplankton biomass ( $\mathrm{mg} \mathrm{DW} \mathrm{m}^{-3}$ ) at which most larvae of the 3 species of each length class $(\mathrm{mm})$ were found.

Potential predation scenarios among tuna larvae: The spatial and temporal overlap of different tuna size classes was described using generalized additive models (GAMs). GAMs are nonparametric extensions of generalized linear models (GLM) but they allow statistical analysis between variables of nonlinear relationship. We used the 'mgcv' library in the R statistical software (www.r-project.org) for the analysis of GAM models. For each species, the response variable in the analyses was the presence/absence $(\mu)$ of Stage 1 and Stage 2 larval stages modeled as a binomial response with the logit function $\log [\mu /(1-\mu)]$. The GAMs were used to test for prey effects, relating presence/absence of Stage 1 and Stage 2 larvae to the other larvae. The criteria used to evaluate the models were based on Wood (2006) and included (1) the unbiased risk estimator or UBRE (the lower the better), (2) the level of deviance explained (the higher the better), and (3) the statistical significance.

Size-dependent natural mortality rates of tuna larvae: We estimated the average frequency by size class $(1 \mathrm{~mm})$ in the catch for the 3 tuna species together (BFT, ALB and BT) in data from 2004 and 2005. Sizedependent natural mortality rates were estimated assuming an average length growth rate of $0.35 \mathrm{~mm}$ $\mathrm{d}^{-1}$ (Garcia et al. 2006), omitting situations with positive rates. Our field-based mortality rates for tuna were compared to the general pattern in natural mortality for marine pelagic fish larvae described by the sizedependent relationship from McGurk (1986) based on published data for different species.

Foraging models. We developed 2 foraging models to evaluate zooplanktivorous and piscivorous feeding in tuna larvae. For planktivory, we calculated the visual range required to obtain maximum potential growth rate at realistic prey densities. Larvae were considered food limited if the required visual range exceeded estimates for other pelagic species in relevant laboratory studies, e.g. Anchoa mitchilli (Chesney 2008), Engraulis mordax (Hunter 1972), and Clupea harengus (Rosenthal \& Hempel 1970). For piscivory, we applied a similar foraging model, and included growth and mortality of successive cohorts to assess 
the importance of surf-riding on a size spectrum of younger larvae (Pope et al. 1994). The parameterization of the 2 foraging models is mainly from aquaculture studies on bluefin tuna Thunnus thynnus and data from the field. All variables, parameters and sources are summarized in Tables 1 to 3 .

Planktivory model: To construct this model, it was necessary to calculate the visual range required to obtain maximum growth rate on a zooplankton diet (Table 1). The clearance rate $\beta$ of a cruising planktivore searching for food in the pelagic describes the volume searched by the larvae $\left(\mathrm{m}^{3} \mathrm{~s}^{-1}\right)$ and is given by:

$$
\beta=\pi d^{2} V
$$

where $d$ is the visual detection distance (m) and $V$ is the swimming speed $\left(\mathrm{m} \mathrm{s}^{-1}\right)$. The visual range required to find enough prey to sustain maximum potential growth rate ( $d_{\text {maxgr }}$ instead of $d$, also in $\mathrm{m}$ ) can then be expressed as:

$$
d_{\text {maxgr }}=\sqrt{\frac{\beta_{\mathrm{zoo}}}{\pi V}}
$$

where $\beta_{\mathrm{zoo}}$ is the minimum clearance rate $\left(\mathrm{m}^{3} \mathrm{~s}^{-1}\right)$ required to sustain the maximum potential growth rate at a given temperature $T$. We assumed that all encounters lead to ingestion, and that there is no prey handling time, therefore $\beta_{\text {zoo }}$ can be estimated as:

$$
\beta_{\mathrm{zoo}}=\frac{\delta}{t_{f} \times B_{\mathrm{zoo}} \times P C_{\mathrm{zoo}}}
$$

where $\delta$ is the temperature-dependent ingestion required to sustain potential growth rates (in $\mu \mathrm{g}$ dry mass, see 'Bioenergetic model'). $t_{f}$ is the time that larvae spend for feeding during the day, which we assumed to be $14 \mathrm{~h} \mathrm{~d}^{-1}$ based on findings from surveys of the daily cycle showing tuna larvae to have gut fullness of $>50 \%$ over 14 h (Morote et al. 2008). Because there is no data on the mesozooplankton prey size spectra or prey species composition from the field sampling, we assumed that at stations with sampled larvae, all zooplankton are potential prey $\left(B_{\mathrm{zoo}}\right.$ in $\left.\mu \mathrm{g} \mathrm{DW} \mathrm{m}^{-3}\right)$. We assumed that the capture probability $\left(P_{C_{\mathrm{zoo}}}\right)$ of mesozooplankton prey is 1 , as reported in the laboratory for yellowfin tuna at first feeding (Margulies 1997). Because there is no data on mesozooplankton prey size spectra or prey composition from the field sampling, we assumed that all zooplankton biomass is potential food, which is a conservative assumption for the ability of larvae to survive on planktivory.
Piscivory model: This model was developed to estimate the mortality rates on the larval population due to cannibalism (Table 2). The mortality rate $M_{i}$ in cohort $i$, caused by predation from piscivorous larvae is modeled as a classical Holling disk process with multiple prey:

$$
M_{i}=\sum_{j=1}^{n_{j}} \frac{N_{p j} e_{i j} P C_{i j}}{1+\sum_{i=1}^{n_{i}} e_{i j} h}
$$

where $n_{j}$ is the number of piscivorous cohorts that can prey on cohort number $i$ and $n_{i}$ is the number of possible prey cohorts for the piscivorous larvae of cohort $j$. $N_{p j}$ is the density of piscivorous larvae in cohort $j$ (ind. $\mathrm{m}^{-3}$ ), $P C_{i j}$ is the capture probability of a larva in cohort $i$ by a piscivorous larva in cohort $j$, and $h$ is prey handling time $(1 \mathrm{~s})$. The encounter rate $e_{i j}$ between a piscivorous larva in cohort $j$ and a potential prey larva in cohort $i$ (ind. $\mathrm{s}^{-1}$ ) is:

$$
e_{i j}=\beta_{i j} N_{i}
$$

where $\beta_{i j}$ is the clearance rate $\left(\mathrm{m}^{3} \mathrm{~s}^{-1}\right)$ and $N_{i}$ is the density of cohort $i$ (ind. $\mathrm{m}^{-3}$ ). Clearance rates for piscivory were modeled as:

$$
\beta_{i j}=\pi r_{i j}^{2} W_{i j}
$$

where $w_{i j}$ is the relative swimming speed $\left(\mathrm{m} \mathrm{s}^{-1}\right)$ between a predator larva in cohort $j$ and a prey larva in cohort $i$ and $r$ is the larval predator visual perception distance (in $\mathrm{m}$, see Appendix 1 for details). $w_{i j}$ was estimated as a function of the prey $\left(u_{i}\right)$ and predator $\left(v_{j}\right)$ swimming speeds (all units in $\mathrm{m} \mathrm{s}^{-1}$; Gerritsen \& Strickler 1977):

$$
w_{i j}=\frac{u_{i}^{2}+3 v_{j}^{2}}{3 v_{j}}
$$

\begin{tabular}{|c|c|c|c|}
\hline Symbol & Description & Unit & Eq. \\
\hline$\beta$ & Clearance rate of a planktivorous larva & $\mathrm{m}^{3} \mathrm{~s}^{-1}$ & 1 \\
\hline$d$ & Visual detection distance & $\mathrm{m}$ & 1 \\
\hline$V$ & Larval swimming speed & $\mathrm{m} \mathrm{s}^{-1}$ & 1,2 \\
\hline$d_{\text {maxgr }}$ & $\begin{array}{l}\text { Larval visual range required for maximum } \\
\text { potential growth }\end{array}$ & $\mathrm{m}$ & 2 \\
\hline$\beta_{\mathrm{zoo}}$ & $\begin{array}{l}\text { Minimum clearance rate of a planktivorous larva to } \\
\text { sustain maximum potential growth }\end{array}$ & $\mathrm{m}^{3} \mathrm{~s}^{-1}$ & 2,3 \\
\hline$\delta$ & $\begin{array}{l}\text { Temperature-dependent required diel ingestion } \\
\text { to sustain maximum potential growth }\end{array}$ & $\mu g$ & 3,9 \\
\hline$t_{f}$ & Time larvae spend feeding during the day & $\mathrm{s}$ & 3 \\
\hline$B_{\text {zoo }}$ & Mesozooplankton biomass in the field & $\mu \mathrm{g} \mathrm{m} \mathrm{m}^{-3}$ & 3 \\
\hline$P C_{\mathrm{zoo}}$ & Capture probability feeding zooplankton & Dim. $^{a}$ & 3 \\
\hline \multicolumn{4}{|c|}{${ }^{\mathrm{a}}$ Value $=1$} \\
\hline
\end{tabular}

We modeled the capture success $P_{C}$ as a linear relationship between the relative sizes of prey and preda-

Table 1. Variables and parameters used in the model for planktivory. Dim: dimensionless 
Table 2. Variables and parameters used in the model for piscivory. Dim.: dimensionless

\begin{tabular}{|c|c|c|c|}
\hline Symbol & Description & Unit & Eq. \\
\hline$M_{i}$ & $\begin{array}{l}\text { Mortality rate in cohort } i \text { caused by predation } \\
\text { from piscivorous larvae }\end{array}$ & $\begin{array}{l}\text { ind. } \\
\mathrm{m}^{-3} \mathrm{~s}^{-1}\end{array}$ & 4 \\
\hline$n_{j}$ & $\begin{array}{l}\text { Number of piscivorous cohorts that can prey } \\
\text { on cohort } i\end{array}$ & & 4 \\
\hline$n_{i}$ & $\begin{array}{l}\text { Number of possible prey cohorts for the } \\
\text { piscivorous larvae of cohort } j\end{array}$ & & 4 \\
\hline$N p_{j}$ & Density of piscivorous larvae in cohort $j$ & ind. $\mathrm{m}^{-3}$ & 4 \\
\hline$e_{i j}$ & $\begin{array}{l}\text { Encounter rate of a piscivorous larva in cohort } j \\
\text { with a larva of cohort } i\end{array}$ & ind. $\mathrm{s}^{-1}$ & 4,5 \\
\hline$P_{C_{i j}}$ & $\begin{array}{l}\text { Capture probability of a larva in cohort } i \text { by a } \\
\text { piscivorous larva in cohort } j\end{array}$ & Dim. & 4 \\
\hline$h$ & Prey handling time ${ }^{a}$ & $\mathrm{~s}$ & 4 \\
\hline$\beta_{i j}$ & $\begin{array}{l}\text { Clearance rate of a piscivorous larva in cohort } j \\
\text { feeding on larval prey in cohort } i\end{array}$ & $\mathrm{~m}^{3} \mathrm{~s}^{-1}$ & 5,6 \\
\hline$N_{i}$ & Density of prey larvae in cohort $i$ & ind. $\mathrm{m}^{-3}$ & 5 \\
\hline$r$ & Predator visual perception distance & $\mathrm{m}$ & 6 \\
\hline$W_{i j}$ & Relative swimming speed ${ }^{\mathrm{b}}$ & $\mathrm{m} \mathrm{s}^{-1}$ & 6,7 \\
\hline$u$ & Larval prey swimming speed & $\mathrm{m} \mathrm{s}^{-1}$ & 7 \\
\hline V & Larval predator swimming speed & $\mathrm{m} \mathrm{s}^{-1}$ & 7 \\
\hline SL & Larval standard length & $\mathrm{mm}$ & 8 \\
\hline LJL & Larval predator lower jaw length ${ }^{c}$ & $\mathrm{~mm}$ & 8 \\
\hline a & Capture efficiency $^{\mathrm{d}}$ & Dim. & \\
\hline
\end{tabular}

tor. The capture success is 0 when the prey is the same size or larger than the predator's lower jaw length (LJL) and decreases linearly with a slope a over prey size. The parameter a defines the efficiency of capture and reflects the ability of a larval predator to capture a larval prey. The range for a reported for piscivorous juveniles as estimated from the slope of the linear regression between the proportions of successful captures and the prey/predator length ratio, varies around -2 (Scharf et al. 1998). We re-calculated this value as a function of the larval prey width/larval predator lower jaw length ratio using the expression estimated for Thunnus alalunga larvae (Catalán et al. 2007) as:

$$
\mathrm{LJL}=-0.4055+0.272 \mathrm{SL}
$$

with all lengths in $\mathrm{mm}$ resulting in $a=-5$.

Bioenergetic model. We developed a simple bioenergetic model (Table 3) to calculate the diel ingestion required to sustain maximum potential growth rates of tuna larvae at different body sizes and temperatures ( $\delta$ in the planktivorous model). The bioenergetic model resembles those developed by Kristiansen et al. (2007) and Urtizberea et al. (2008) for cod and anchovy larvae respectively. The ingested food passes to the gut where it is digested and made available for metabolic and growth processes. Under satiated conditions, the larvae achieve the temperature-dependent maximum growth rate. Under food limited conditions, growth depends on the temperature dependent metabolic cost and the amount of prey mass ingested. The diel ingestion required to sustain maximum potential growth rates $(\delta, \mu \mathrm{g}$ dry mass) is then given by:

$$
\delta=\frac{(\mathrm{SGR} \times W)+R}{\mathrm{AE}} t_{f}
$$

where SGR is the maximum potential specific growth rate $\left(\mu \mathrm{g} \mu \mathrm{g}^{-1} \mathrm{~s}^{-1}\right), W$ is the larval dry weight $(\mu \mathrm{g}), R$ is the routine metabolic cost $\left(\mu \mathrm{g} \mathrm{s}^{-1}\right), \mathrm{AE}$ is the assimilation efficiency (dimensionless) and $t_{f}$ is the time (s) that larvae spend for feeding during the day, which we assumed to be $14 \mathrm{~h} \mathrm{~d}^{-1}$ (i.e. $50400 \mathrm{~s} \mathrm{~d}^{-1}$ ).

Maximum specific growth rate: Maximum potential growth rates were obtained using age-length relationships from laboratory experiments in Pacific bluefin tuna larvae Thunnus thynnus orientalis (up to

\begin{tabular}{|c|c|c|c|c|}
\hline Symbol & Description & Unit & Value; source & Eq. \\
\hline \multicolumn{5}{|c|}{ Bioenergetic model } \\
\hline SGR & Specific growth rate for tuna & $\mu g \mu g^{-1} s^{-1}$ & $\begin{array}{l}\text { Miyashita et al. (2001), } \\
\text { Sawada et al. (2005), } \\
\text { Tanaka et al. (2008) }\end{array}$ & 9,10 \\
\hline$R$ & Routine metabolic cost & $\mu \mathrm{g} \mathrm{s}^{-1}$ & Miyashita et al. (1999) & 9,11 \\
\hline$W$ & Larval dry weight & $\mu g$ & & 9,11 \\
\hline $\mathrm{AE}$ & Assimilation efficiency & Dimensionless & 0.77; Fraser et al. (1998) & 9 \\
\hline$T$ & Temperature & ${ }^{\circ} \mathrm{C}$ & & 10,11 \\
\hline$Q_{10}$ & Quotient for temperature effect on $R$ & Dimensionless & 1.7; Guiguère et al. (1988) & 11 \\
\hline \multicolumn{5}{|c|}{ Simulations } \\
\hline$N M_{i}$ & Size-dependent natural mortality rate & & Present study & 12 \\
\hline$N M_{\text {iMcGurk }}$ & Natural mortality rate from McGurk (1986) & & McGurk (1986) & \\
\hline
\end{tabular}

Table 3. Variables and parameters used in the bioenergetic model and in the simulations 
$\sim 35 \mathrm{~mm}$ ) under controlled temperatures (Miyashita et al. 2001, Sawada et al. 2005, Tanaka et al. 2008). A relationship between age and dry weight was fitted to estimate the maximum potential specific growth rate of Pacific bluefin tuna larvae at each temperature. Although not specifically stated in the laboratory study, we assumed larvae were food-satiated in these experiments. The specific growth rates (SGR) $\left(\mu \mathrm{g} \mu \mathrm{g}^{-1}\right.$ $\mathrm{s}^{-1}$ ) increased with temperature and were explained by a linear relationship with temperature $T$ (see Fig. 2):

$$
\begin{gathered}
\mathrm{SGR}=-6.13 \times 10^{-6}+3.36 \times 10^{-7} T \\
\left(\mathrm{r}^{2}=0.85, \mathrm{p}<0.01, \mathrm{n}=6\right)
\end{gathered}
$$

Routine metabolic cost: Metabolic costs were estimated from laboratory experiments with bluefin tuna at $25^{\circ} \mathrm{C}$ (Miyashita et al. 1999). The data were transformed from $\mu \mathrm{O}_{2} \mathrm{~min}^{-1}$ to $\mu \mathrm{g}$ dry mass by assuming that $1 \mu \mathrm{mol}$ of $\mathrm{O}_{2}$ corresponds to $22.39 \mu \mathrm{l}$ and $1 \mu \mathrm{g}$ of $\mathrm{O}_{2}$ corresponds to $32 \mu \mathrm{mol}$ under standard salinity and temperature. The metabolic cost $\left(\mu \mathrm{g} \mathrm{s}^{-1}\right)$ at $25^{\circ} \mathrm{C}$ was calculated as:

$$
\begin{gathered}
R=4.17 \times 10^{-6} W^{0.91715} \mathrm{e}^{(T-25) \ln Q_{10} / 10} \\
\left(\mathrm{r}^{2}=0.98, \mathrm{p}<0.001, \mathrm{n}=81\right)
\end{gathered}
$$

where $R$ is the larval routine metabolic cost, $W$ is the dry weight, and $Q_{10}$ is the quotient for temperature effect on $R$. The metabolic cost increased with temperature by a $Q_{10}$ of 1.7 in larvae of Scomber scombrus belonging to the same family (Scombridae) (Giguère et al. 1988).

Assimilation efficiency: There are no estimates of assimilation efficiency for tuna and we assumed an assimilation efficiency of $77 \%$ based on Atlantic halibut Hippoglossus hipoglossus feeding on a diet containing ${ }^{15} \mathrm{~N}$-labeled protein (Fraser et al. 1998). This species resembles tuna in stomach morphology and activity of digestive enzymes (Rønnestad et al. 2007).

Diel ingestion required to sustain maximum potential growth rates: The ingestion rate required for the larvae to achieve maximum potential growth rates at $23.5^{\circ} \mathrm{C}$ ( $\delta$ in the planktivorous model) was estimated as $70 \%$ of larval dry weight per day.

Simulation overview. For the larvae foraging on a pure zooplankton diet we calculated the visual range required to obtain the maximum potential growth rate at the zooplankton densities they experience in the field. This was used to assess food limitation under pure planktivory.

To calculate the mortality effect of size-surfing cannibalism, we assumed that larvae hatch over $14 \mathrm{~d}$ ( 1 cohort $\left.\mathrm{d}^{-1}\right)$, which is the average individual duration of the spawning process in an adult BFT female (Medina et al. 2007). Length at hatch was set at $3.5 \mathrm{~mm}$, when the yolk sac is used up, and input densities ranged from 0.01 to 1.2 larvae $\mathrm{m}^{-3}$, which is the range of densities typically observed in the field. For these simulations, we assumed that larval growth rates are temperature-limited but not food-limited. Larvae become piscivorous when they reach $6.5 \mathrm{~mm}$. Our growth model only applies to larvae up to $15 \mathrm{~mm}$, therefore the cohort was removed when the first larvae reached this size. Larval mortality includes purely sizedependent natural background mortality $\left(N M_{i}\right)$, cannibalism or piscivory $\left(M_{i}\right)$ or both $\left(N M_{i}+M_{i}\right)$. Two different formulations were used for natural mortality (Table 3) as obtained from data on tuna abundances in the present study $\left(N M_{i}\right)$ and from the general expression obtained for other species as reported by McGurk (1986) $\left(N M_{i \text { McGurk }}\right)$. We assumed that the spatial dispersal of larvae are limited or counterbalanced by immigration of larvae from neighboring areas, and examined recruitment consequences of cannibalistic interactions as the number of surviving larvae at $7 \mathrm{~mm} \mathrm{SL}$ for different cohorts at increasing hatching densities (0.01 to 1.2 larvae $\mathrm{m}^{-3}$ ).

\section{RESULTS}

\section{Field observations}

\section{Zooplankton biomass concentrations in the field}

Most of the BT larvae were found at mesozooplankton densities of $\sim 8 \mathrm{mg} \mathrm{DW}^{-3}$, but the variability was substantial (Fig. 1). In ALB, larger larvae occurred more frequently at lower and intermediate mesozooplankton densities (Fig. 1). In BFT, the mesozooplankton density decreased with larval size up to $7 \mathrm{~mm}$ but peaked at $8.4 \mathrm{~mm}$. Overall zooplankton densities ranged from 1 to $18 \mathrm{mg} \mathrm{DW} \mathrm{m} \mathrm{m}^{-3}$.

\section{Predation potential among species}

The potential for significant predator-prey interactions among tuna larvae of different sizes in the field was confirmed by the GAM analyses, suggesting that patterns of co-occurrence between different larval stages could be explained in terms of cannibalism or piscivory (Table 4). The statistical analysis suggests that BT1 and BT2 tended to co-occur. There was also a high probability of finding ALB1 where there was BT1. There were few samples with ALB2 and BFT2 but it is likely to find ALB2 with BFT2 and vice versa. BFT2 was also found with ALB1. The co-occurrence of larvae of different sizes in the 3 species can be observed all over the spawning area so the potential for predation exists (Fig. 2). 


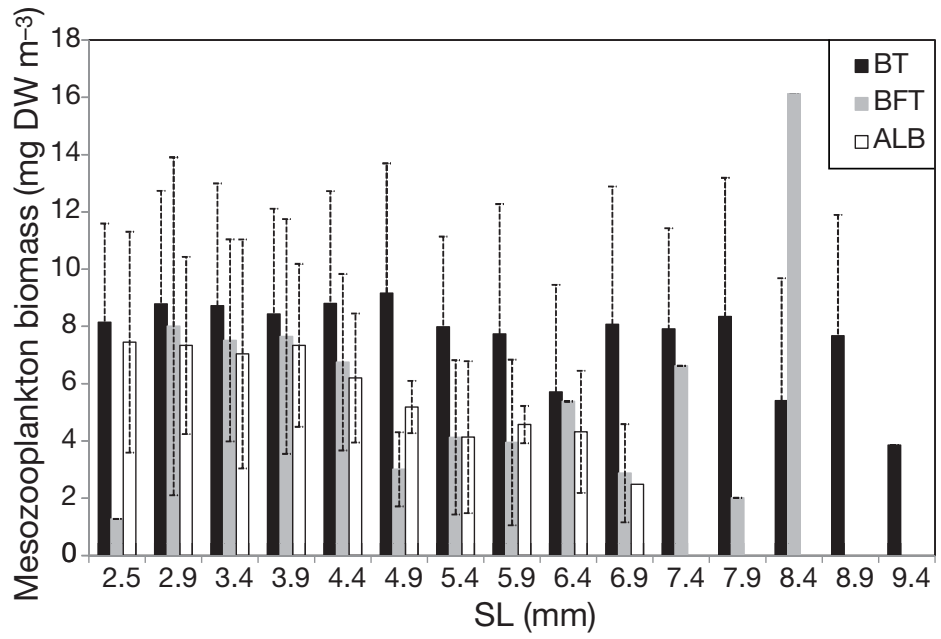

Fig. 1. Auxis rochei, Thunnus alalunga, and Thunnus thynnus. Mean $( \pm \mathrm{SD})$ mesozooplankton biomass $\left(\mathrm{mg} \mathrm{DW} \mathrm{m}^{-3}\right)$ experienced by tuna larvae (separated by larval size range) in the field. SL: standard length; BT: bullet tuna; ALB: albacore tuna; BFT: bluefin tuna

Size-dependent natural mortality rates of tuna larvae

The relationship between size and mortality obtained from our field data was (Fig. 3):

$$
\begin{gathered}
N M=0.393111 \mathrm{SL}^{-0.75} \\
\left(\mathrm{r}^{2}=0.35, \mathrm{p}<0.05, \mathrm{n}=12\right)
\end{gathered}
$$

where $n=12$ is the number of species-specific size classes. The natural mortality rates we estimated for tuna larvae were lower than the general estimate for fish eggs and larvae (McGurk 1986) for the smallest larvae (Fig. 3). The size dependency was also less.

\section{Model simulations}

Foraging on a pure zooplankton diet

The visual prey detection distance required for BFT/ALB larvae to grow at potential maximum rates at the field mesozooplankton densities (assuming all zooplankton are potential prey) were within the range of 1 to 2 body lengths (Fig. 4a). The visual range needed to achieve the required clearance rate was similar to 1 body length at mesozooplankton densities $>7 \mathrm{mg} \mathrm{DW} \mathrm{m}^{-3}$, whereas visual ranges needed to be higher at lower densities (Fig. 4b). Given the conservative assumptions in the model (see above), this suggests that larval growth of tuna is likely to be food limited with a pure zooplankton diet. Larger larvae appear to be more limited by planktivory than smaller larvae as shown by the generally higher visual range/larval length ratios of larger than of smaller larvae. This pattern is more marked for ALB and BFT than for BT.

\section{Mortality effect of size-surfing cannibalism}

We first simulated the impact of cannibalism on larval cohorts at different temperatures (Fig. 5). Cannibalism had a substantial influence on the densities of some of the cohorts over time at temperatures $>24^{\circ} \mathrm{C}$. Reducing temperature to $22^{\circ} \mathrm{C}$ slowed down growth rates and all cohorts survived to the end of the simulations, making the effect of cannibalism negligible (Fig. 5a). At higher temperatures, growth rates accelerated, the size difference between cohorts increased, and larvae were exposed to cannibalism for a longer period (Fig. 5b,c). Only the first and the intermediate cohorts (cohort nos. 1 to 10 at $24^{\circ} \mathrm{C}$ and nos. 1 to 13 at $26^{\circ} \mathrm{C}$ ) survived up to the end of the simulation time (Fig. 5b,c). The rest of the cohorts were preyed upon to densities $<10^{-4}$ larvae $\mathrm{m}^{-3}$.

If cannibalism was the only source of mortality and larvae grew at food-satiated rates, recruitment (density at size $7 \mathrm{~mm}$ ) was negatively related to egg production (density at hatch) and temperature (Fig. 6a,b). At low temperatures, the size difference in the cohort did not

Table 4. Estimated significance $(\sim \mathrm{s})$ of the presence/absence relationship of each species at Stages 1 and 2 with respect to the other species, based on generalized additive models (GAM). BT1, BT2: bullet tuna Stages 1 and 2; ALB1, ALB2: albacore Stages 1 and 2; and BFT1, BFT2: bluefin tuna Stages 1 and 2. Dev.\%: level of deviance explained (the higher the better). UBRE: unbiased risk estimator (the lower the better). ns: not significant; ${ }^{*} p<0.05$;

\begin{tabular}{|c|c|c|c|c|c|c|}
\hline \multirow[t]{2}{*}{ Variable } & \multicolumn{2}{|c|}{ BT } & \multicolumn{2}{|c|}{ ALB } & \multicolumn{2}{|c|}{ BFT } \\
\hline & Dev.\% & UBRE & Dev.\% & UBRE & Dev.\% & UBRE \\
\hline \multicolumn{7}{|l|}{ Stage 1} \\
\hline$\sim \mathrm{S}(\mathrm{BT} 1)$ & & & 15.2 & $0.07^{*}$ & 1.78 & $-0.46^{\mathrm{ns}}$ \\
\hline$\sim \mathrm{S}(\mathrm{ALB} 1)$ & 13.7 & $0.22^{*}$ & & & 5.07 & $-0.46^{\mathrm{ns}}$ \\
\hline$\sim \mathrm{s}(\mathrm{BFT} 1)$ & 0.26 & $0.38^{\text {ns }}$ & 3.11 & $0.18^{\text {ns }}$ & & \\
\hline$\sim \mathrm{S}(\mathrm{BT} 2)$ & $8^{*}$ & ** & 5.23 & $0.15^{*}$ & 0.09 & $-0.45^{\mathrm{ns}}$ \\
\hline$\sim \mathrm{S}(\mathrm{ALB} 2)$ & 1.04 & $0.36^{\text {ns }}$ & 1.09 & $0.19^{\text {ns }}$ & 0.32 & $-0.45^{\mathrm{ns}}$ \\
\hline$\sim \mathrm{s}(\mathrm{BFT} 2)$ & 0.27 & $0.38^{\text {ns }}$ & 0.66 & $0.2^{\text {ns }}$ & 1.16 & $-0.45^{\mathrm{ns}}$ \\
\hline \multicolumn{7}{|l|}{ Stage 2} \\
\hline$\sim \mathrm{s}(\mathrm{BT} 2)$ & & & 0.29 & $-0.59^{\text {ns }}$ & 0.37 & $-0.57^{\mathrm{ns}}$ \\
\hline$\sim \mathrm{S}(\mathrm{ALB} 2)$ & 2.26 & $0.13^{\text {ns }}$ & & & 8.6 & ${ }^{* *}$ \\
\hline$\sim \mathrm{s}(\mathrm{BFT} 2)$ & 2.38 & $0.14^{\mathrm{ns}}$ & 8 & $* *$ & & \\
\hline$\sim \mathrm{S}(\mathrm{BT} 1)$ & 9.07 & $0.06^{*}$ & 0.02 & $-0.59^{\mathrm{ns}}$ & 0.49 & $-0.57^{\mathrm{ns}}$ \\
\hline$\sim \mathrm{S}(\mathrm{ALB} 1)$ & 6.19 & $0.09^{*}$ & 5.82 & $-0.6^{\mathrm{ns}}$ & 4.2 & ${ }^{* *}$ \\
\hline$\sim \mathrm{s}(\mathrm{BFT} 1)$ & 0.28 & $0.14^{\mathrm{ns}}$ & 0.07 & $-0.59^{\mathrm{ns}}$ & 4.33 & $-0.58^{\text {ns }}$ \\
\hline
\end{tabular}
${ }^{* *}$ generalized linear models (GLM) instead of GAM 


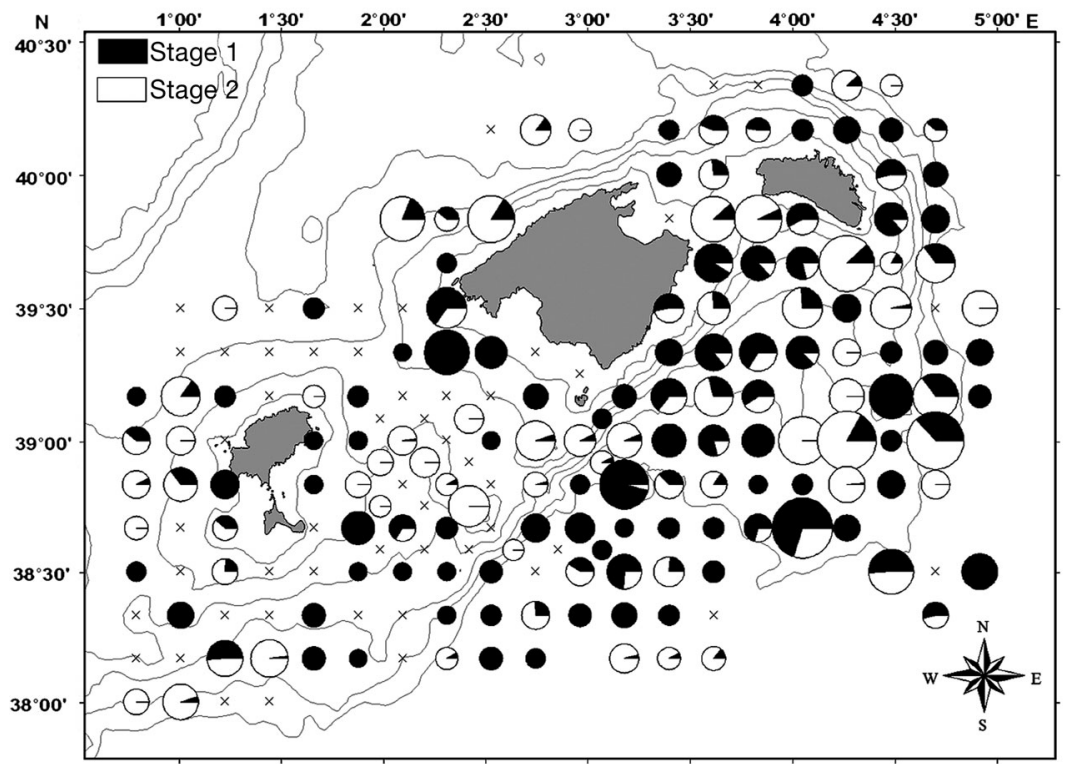

Fig. 2. Auxis rochei, Thunnus alalunga, and Thunnus thynnus. Occurrence of Stage 1 and Stage 2 larvae. The abundances of each stage were added for both years (2004 and 2005). Sizes of pie charts are scaled to larval densities.

$(\times)$ sampled stations with no tuna larvae caught

become large enough for cannibalism to operate (see curve for $22^{\circ} \mathrm{C}$ in Fig. 6a,b). As temperature increased, cannibalism acted more strongly (Fig. 6a,b); at the highest temperatures, cohorts became depleted even at the lowest egg productions (Fig. 6b). When sizedependent mortalities were introduced in addition to cannibalism, the situation became more complex. Larvae should survive better when they are growing faster but instead, the size structure facilitated cannibalism at higher temperatures (Fig. 6c-f). At low densities, the size-mortality effect of temperature dominated but at higher densities, size diversification and cannibalism were more important for the survival of later cohorts. At $22^{\circ} \mathrm{C}$ and below, cannibalism did not occur and recruitment was proportional to initial density. At higher temperatures, cannibalism made recruitment increasingly compensating, and even overcompensating (Fig. 6c-f). The mortality function from McGurk (1986) had stronger size dependence than the estimated mortality in smaller larval tuna but was weaker for the larger larvae. Therefore, warmer water may be less beneficial for recruitment in this case where exercised mortality on smaller larval sizes was stronger (Fig. 6e-f).

The size structure of the tuna larvae after $30 \mathrm{~d}$ differed depending on the temperature and the mortality function used in the simulations (Fig. 7). Most commonly, a dome-shape size range was observed. At the coldest temperatures $\left(22^{\circ} \mathrm{C}\right)$, the density of the larvae decreased with size as only size-dependent mortality was acting on the larvae. At warmer temperatures (24 to $26^{\circ} \mathrm{C}$ ), larger larvae were more abundant than smaller ones, which could be explained by the stronger cannibalistic behavior of the former at the highest temperatures $\left(26^{\circ} \mathrm{C}\right)$.

The simulations run at $24^{\circ} \mathrm{C}$ using hatching densities between 0.02 to 0.2 larvae $\mathrm{m}^{-3}$ and combining cannibalism mortality and size-dependent mortality (with both $N M$ for tuna and NM by McGurk 1986) resulted in cohort densities that were within range of the observed cohort densities from in situ data (Fig. 8). The estimated $N M$ for tuna fitted observed variations in average cohort densities better than the $N M_{\text {McGurk }}$ at lower hatching densities $(0.02$ to 0.05 larvae $\mathrm{m}^{-3}$ ).

\section{DISCUSSION}

The basis for the theory developed by Pope et al. (1994) is that successful larvae need to grow on abundant food of smaller size and at the same time avoid co-evolving predators of larger size. We suggest this to be a main issue for the survival of early-piscivorous larvae spawned in relatively oligotrophic areas where the abundance of plankton may not be sufficient to sustain maximum potential growth rates.

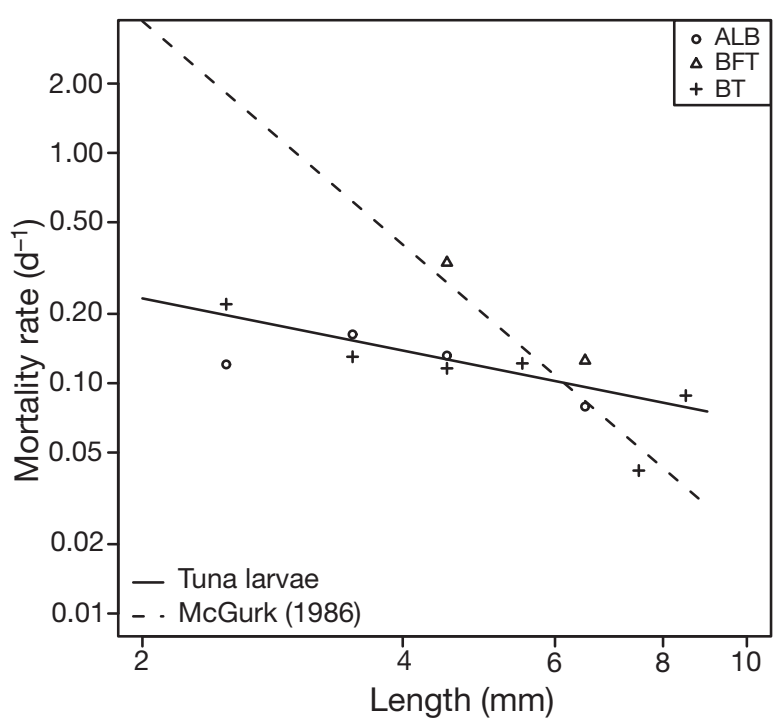

Fig. 3. Auxis rochei, Thunnus alalunga, and Thunnus thynnus. Size-dependent natural mortality estimates from field data, calculated as the differences in abundances between consecutive sizes. BT: bullet tuna; ALB: albacore tuna; BFT: bluefin tuna. Data obtained using Eq. (1) (solid line) compared to that reported by McGurk (1986) (broken line, Eq. 2) 

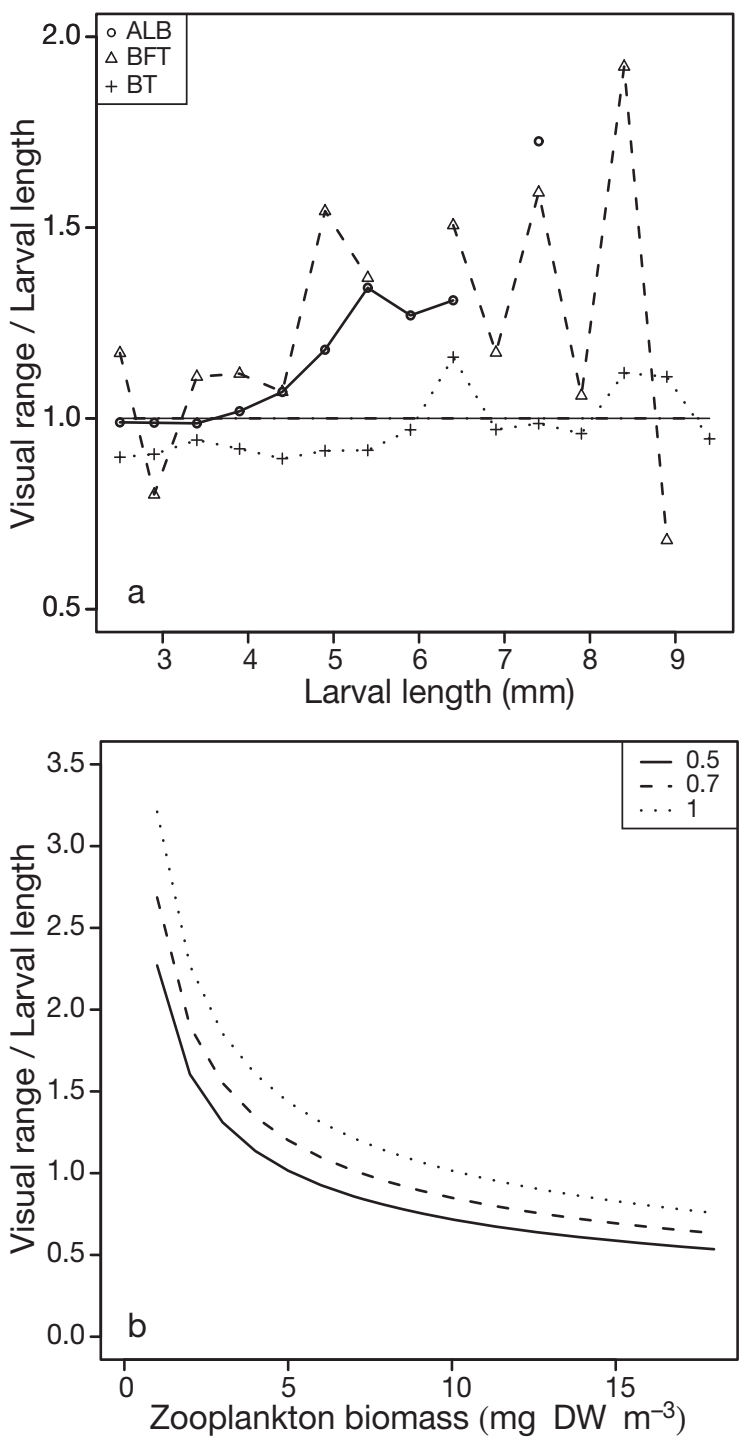

Fig. 4. Auxis rochei, Thunnus alalunga, and Thunnus thynnus. (a) Calculated visual range (in terms of body lengths) required to obtain maximum growth rates for larvae feeding on mesozooplankton at densities encountered in the field (see Fig. 5). BT: bullet tuna; ALB: albacore tuna; BFT: bluefin tuna. (b) Visual range/larval length required to obtain the potential growth rate at different mesozooplankton biomasses and at daily ingestion rates of 50,70 and $100 \%$ of larval dry weight

\section{Field observations}

\section{Zooplankton biomass concentrations experienced by larvae}

The majority of tuna species appear together in oligotrophic tropical and temperate environments. Interestingly, the highest densities of tuna larvae are often found in the least productive waters (Alemany et
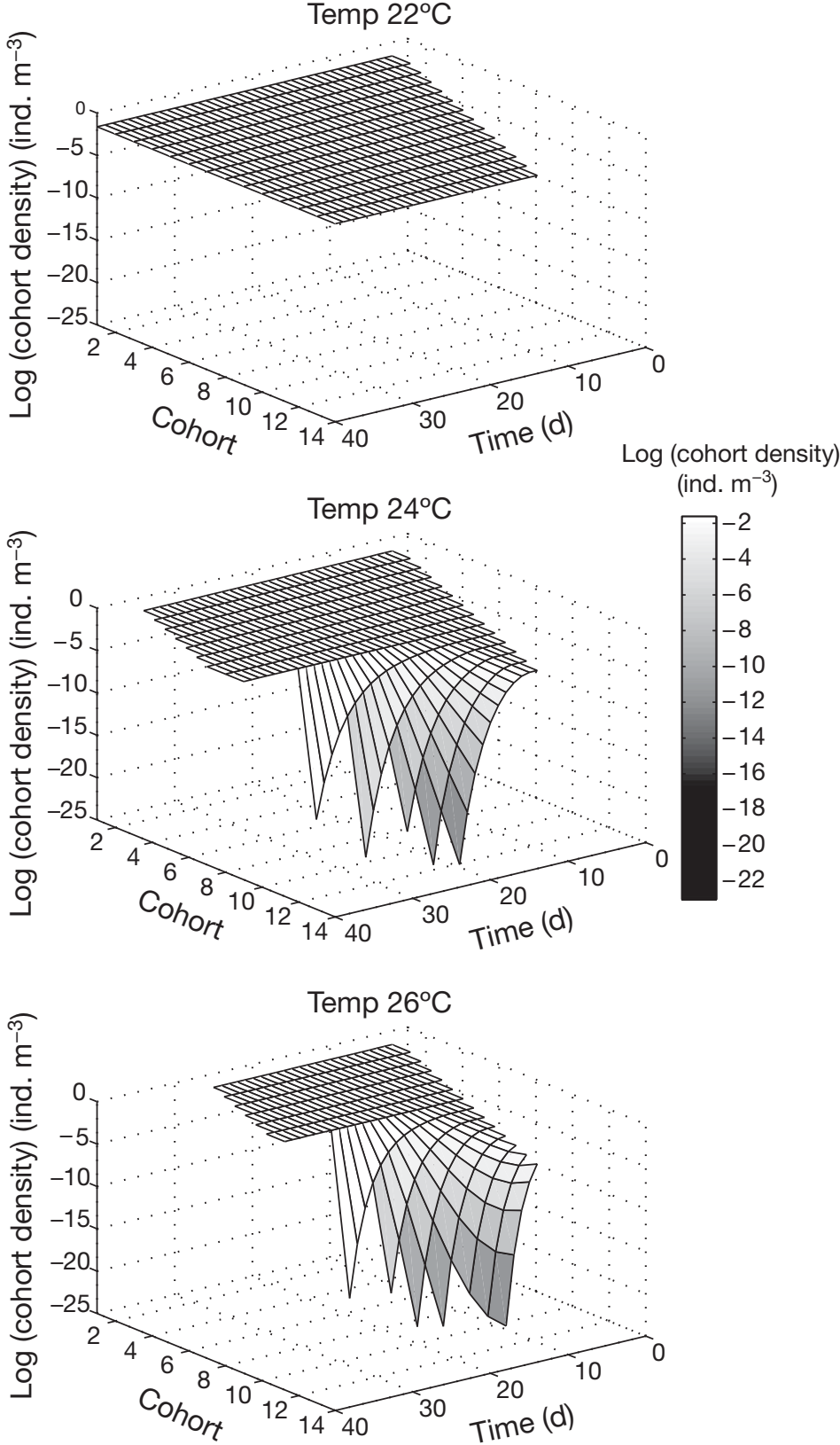

Fig. 5. Auxis rochei, Thunnus alalunga, and Thunnus thynnus. Densities ( $z$-axis, logarithmic scale) of each cohort (indicated by numbers on $x$-axis) at different days ( $y$-axis ) for cohorts growing at 22,24 and $26^{\circ} \mathrm{C}$ assuming only mortality due to predation and no size dependent mortality. Simulations include the capture efficiency with slope $a=-5$ and larval hatching densities of 0.2 larvae $\mathrm{m}^{-3}$

al. 2006, 2010, present study). The actual depth of tuna larval occurrence is usually confined to the upper mixed layer above 20-25 m depth (Davis et al. 1990, Morote et al. 2008, Llopiz et al. 2010, Satoh 2010). We have made an assessment of zooplanktivory based on field mesozooplankton biomasses sampled for the water column integrating from $0-70 \mathrm{~m}$, thus providing 

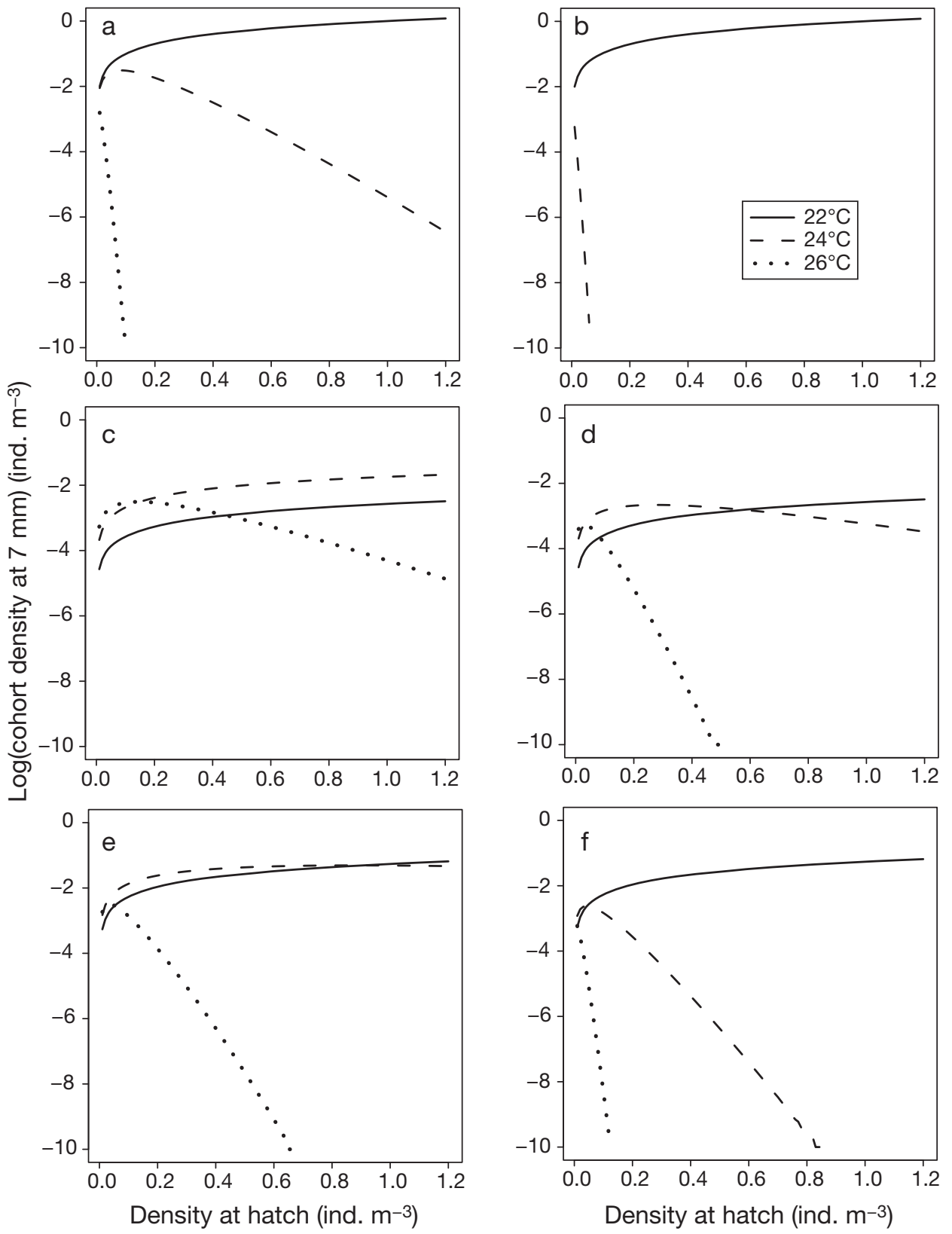

Fig. 6. Auxis rochei, Thunnus alalunga, and Thunnus thynnus. Total number of larvae surviving to 7 mm with increasing initial density at hatching under different temperatures considering only $(a, b)$ the effect of cannibalism, $(c, d)$ the effects of cannibalism and the size-dependent mortality function from McGurk (1986), and (e,f) the effects of cannibalism and size-dependent natural mortality estimated for tuna. Simulations were run for cohorts hatched on Day $10(\mathrm{a}, \mathrm{c}, \mathrm{e})$ and Day 13 (b,d,f), each for 3 temperatures

a maximum mesozooplankton biomass and giving a conservative estimate of zooplanktivory. Tuna larvae show high prey selectivity and the taxonomic composition of the diet changes with ontogeny when feeding on plankton (Catalán et al. 2007, Morote et al. 2008, Llopiz et al. 2010). These increase the likelihood of food limitation with a pure plankton diet, especially in larger larvae and in species occupying poorer waters (BFT and ALB).

\section{Predation potential among species}

Possible competition and predation scenarios among tuna larvae are justified since summer Mediterranean assemblages around the Balearic Islands show high proportions of the 3 tuna species clearly dominating in abundance compared to any other species (Alemany et al. 2006). Larvae of different tuna species are found together in many areas worldwide (Davis et al. 1990, 


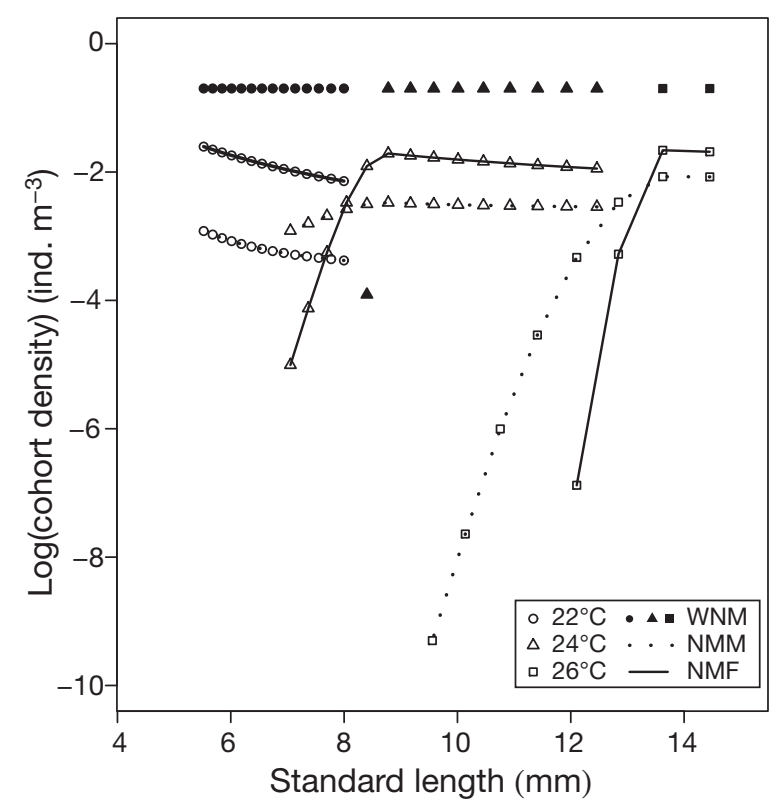

Fig. 7. Auxis rochei, Thunnus alalunga, and Thunnus thynnus. Calculated density and size (standard length) of every cohort of tuna larvae at Day 30. Simulations were run at 22, 24 and $26^{\circ} \mathrm{C}$, considering only the effect of cannibalism (WNM), and the effects of cannibalism and size-dependent mortality from McGurk (1986) (NMM) and from field data (NMF). Density at hatch was 0.2 ind. $\mathrm{m}^{-3}$

Young \& Davis 1990, Beckley \& Leis 2000), dominating in abundances compared to other larval fish species (Miller 1979, Leis et al. 1991, Llopiz et al. 2010). Most larval assemblages for tuna have been described in terms of densities (Davis et al. 1990, Boehlert \& Mundy 1993). The few existing data on larval size distributions provide support for the spatial coexistence of planktivorous preflexion and piscivorous postflexion larval stages of tuna species (Catalán et al. 2007, Morote et al. 2008, Llopiz et al. 2010). Based on the literature cited above, this study assumed that scombrids represent a major proportion in the composition of the larval assemblage. However, quantifying the proportion represented by tuna species compared to the total abundance of larvae above the thermocline where most tuna larvae inhabit is necessary and would improve any estimate of potential effects of piscivory and cannibalism in tuna recruitment.

It is difficult to determine the feeding habits of larger tuna larvae from stomach data, but we know that feeding on other fish larvae is already possible when they are $\sim 6 \mathrm{~mm}$ long (Miyashita et al. 2001, Catalán et al. 2007, Morote et al. 2008, Llopiz et al. 2010), and even earlier in other scombrids (Shoji \& Tanaka 2001, Kaji et al. 2002). The evidence for the switch from a zooplanktivorous to a piscivirous diet is clear from laboratory work where tuna larvae were observed to consume

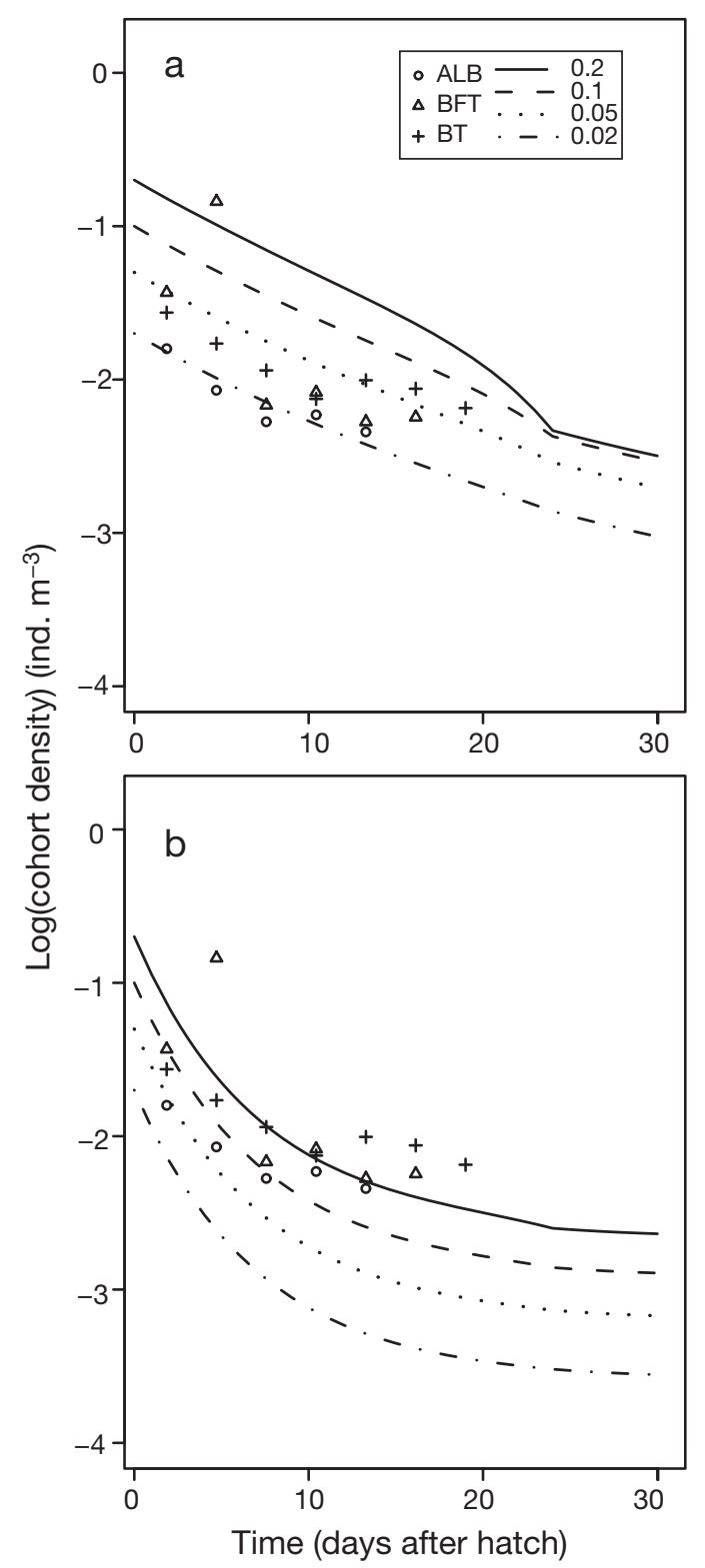

Fig. 8. Auxis rochei, Thunnus alalunga, and Thunnus thynnus. Comparison between observed (symbols as in Fig. 3) and simulated (lines) larval densities over time. Average densities by size from the field were transformed to densities by age using the expression of Garcia et al. (2006) for the 3 species. BT: bullet tuna; ALB: albacore tuna; BFT: bluefin tuna. Simulated densities were estimated for Cohort 10 assuming different hatching densities at $24^{\circ} \mathrm{C}$, and combining cannibalism and natural mortality (NM) estimated (a) for tuna, and (b) by McGurk (1986)

yolk-sac larvae of other species (Seoka et al. 2007), becoming cannibalistic if they were not fed with enough live fish larvae of other species (Sawada et al. 2005). However, identifiying the species of larval prey from field samples is very difficult due to digestion of prey and most field studies avoid it, resulting in more reports 
pointing to piscivory rather than cannibalism. Cannibalism in field-caught tuna has been specifically reported in Thunnus maccoyii larvae (Young \& Davis 1990), whereas interspecific piscivory has been documented in T. alalunga feeding on Auxis rochei (Catalán et al. 2007). However, piscivory without species identification of the fish larvae in the stomachs has been reported in bullet tuna (Morote et al. 2008). In a thorough study analysing stomachs of tuna larvae, Llopiz et al. (2010) also reported larval prey in Thunnus sp., Katsuwonus pelamis and Euthynnus alleteratus with frequencies of occurrence in the stomachs of up to $40 \%$. Further detailed analyses of stomach contents for identification down to species level will help in quantifying piscivory and/or cannibalism among tuna species.

Size-dependent natural mortality rates of tuna larvae

The lower natural mortality rates of tuna larvae compared to the general patterns for fish larvae may reflect the oligotrophic nature of the spawning areas of tuna, which contain fewer predators than more productive systems. Alternatively, our mortality rates may have been underestimated given the highly patchy distribution of the smallest larvae. Overestimation may also be possible since the largest tuna larvae are capable of avoiding the net.

\section{Model simulations}

Foraging on a pure zooplankton diet

The effect of planktivorous fish predation on the size distribution of zooplankton has received much attention in the literature (Brooks \& Dodson 1965, Persson \& De Roos 2006). Our simulations suggest that smaller larvae may sustain their maximum growth potential on mesozooplankton resource levels in the field. However, the visual ranges based on mesozooplankton may be underestimated because we did not include capture processes and size-dependent assimilation efficiency, and we assumed all biomass to be potential prey of an ideal size.

\section{Mortality effect of size-surfing cannibalism}

Cannibalism is relatively common in many fish species (Polis 1981, Smith \& Reay 1991). In general, it has received more attention in larvae of freshwater fish and amphibians than in marine species although it has been suggested to also play a major role in marine fish (Folkvord 1997).
We have developed a tool to calculate the impact of cannibalism using temperature, duration of the hatching period, hatching larval densities and natural mortality rates. At the beginning of the hatching period, successive larval cohorts may escape from predation because larval predators hatched earlier may not yet have achieved the minimum size to become piscivirous. In our model, the effect of piscivory becomes important at $22^{\circ} \mathrm{C}$; however, as temperature increases, prey-predator interactions between cohorts occur more rapidly due to faster larval growth in the warmer water, and more cohorts of predators can feed on the same cohort of prey. The effect of temperature was also observed in the recruitment relationships. Thus, temperature influences cohort densities during the hatching period and the resulting recruitments by driving the intensity of piscivory and cannibalism that is strongly coupled to the growth of both predators and prey (Rice et al. 1997, Claessen et al. 2000). Despite interspecific differences, tuna generally spawn in the Balearic Sea when temperatures are between 20 to $27^{\circ} \mathrm{C}$, coinciding with the warming of the surface water layer during the summer (Alemany et al. 2010). Therefore, our simulations are capturing processes that can occur during the hatching period of tuna. These temperatures are a bit lower than the preferred range of 25 to $30^{\circ} \mathrm{C}$ described for tuna larvae in general (Boyce et al. 2008).

We have discussed the results from our simulations in terms of cannibalism. However, they can also be used to infer the effect of piscivory among cohorts from different tuna species since temporal and spatial overlap among tuna species occur. Our model assumed a fixed input of eggs into a parcel of water for a limited period of time, and therefore simulates a singular spawning event rather than the survival of whole yearclasses. In reality, a mixture of spawning events in different areas will generate a spatial mix of size classes and species. Clearly, such spatial mixing of size classes will eliminate or at least modify the impact of temperature that we see here, as potential cannibals will also appear in colder waters. We have not assessed the implications of spatial overlap between larvae from different batches here, as it depends on a mixture of parental spawning strategies, ocean current systems and larval fish swimming and behaviour (Fiksen et al. 2007). This mixing might facilitate the compensatory effect generated by cannibalism independent of temperature.

The early switch to piscivory may be a necessity for fast-growing larvae in oligotrophic regions. Differences in growth rate on a cannibalistic or piscivorous diet versus a zooplankton diet are expected due to differences in (1) the time spent handling each prey type, (2) the relative abundances of and encounters 
with conspecific and heterospecific larval prey or zooplankton prey, and (3) the assimilation efficiencies for the different prey types. We expect that larvae would spend more time handling zooplankton prey than larval prey since zooplankton feeding requires more prey encounters and captures than fish larval feeding to achieve the same ingestion rates. Physiologically, assimilation efficiencies are expected to be higher with larval feeding than with zooplankton feeding. Future growth may also be affected by piscivory or planktivory during the early larval stage. In the laboratory, bluefin tuna larvae fed with yolk-sac fish larvae showed higher growth and survival compared to the ones fed with enriched Artemia (Seoka et al. 2007). Yolk-sac larvae of marine fish contain nutrients in water-soluble form and are therefore highly valuable as food (Seoka et al. 2008). Even swimming abilities seemed to be favored by feeding on yolk-sac larvae early in larval life (Masuda et al. 2002).

Cannibalism and/or piscivory are size-dependent interactions and can have a strong impact on the size structure of the larvae. The relative abundances of small and large larvae can vary at different temperatures, hatching larval densities and natural mortality rates driven by predation of earlier hatched cohorts on later hatched cohorts. These processes have not been previously accounted for but could be of importance for species interactions and the size structure of communities where tuna larvae dominate.

\section{Summary and broader potential implications}

Our model suggests that predation among larvae from successive cohorts or spawning events is potentially a key factor in the survival, growth, abundance and recruitment of tuna. We have focused only on the early life stages but this may also have consequences for parental fitness and spawning strategies. The spawning strategy of tuna includes long distance migration to spawn in warm waters of low productivity (Graham \& Dickson 2004, Boyce et al. 2008) but high larval abundances of several species of tuna. An interesting hypothesis is that this could be an evolutionary adaptation to keep predation on eggs and larvae low. Our simulations suggest that later batches of eggs are of less value in terms of parental fitness than the earlier ones since most larvae hatched later are more susceptible to cannibalism.

The results in this study might be tested with more detailed field data. Our aim was to describe how piscivory among the early stages contributes to larval mortality rates. The window of vulnerability for late-hatch larvae varies depending on the density of predators and prey. Larvae are more vulnerable to predation from the moment they are hatched when the density of predators is higher and the density of prey is lower. An earlier shift and a shorter duration of the transition between planktivory and cannibalism and/or piscivory in earlierhatch larvae will result in a prolonged vulnerability window for late-hatch larvae. Further efforts in identifying fish prey species in the stomachs will help in evaluating the importance of cannibalism versus piscivory among cohorts of different tuna species and the variability in the piscivorous diet. Our model could be extended to include energetic requirements and assimilation efficiencies during the piscivory phase; however, it is first necessary to improve the parameterization of our bioenergetic model by focused experimentation and field work. This way, cannibalism and piscivory mortality for the later-hatched larvae could be quantified based on the consumption and the energetic demands of the earlier-hatch larvae.

The mean surface temperatures within the mixed surface layers in the study area can vary by $5^{\circ} \mathrm{C}$ during the tuna spawning season and by a broader range for the extreme temperature values (Alemany et al. 2010). Given that one of our main findings is the temperature dependence of cannibalistic mortality, recruitment variability from year to year may be expected due to slight variations in temperature over the spawning season. In the long term, effects of piscivory on survival may become stronger if average surface temperatures tend to increase in the Mediterranean as suggested in some studies (Salat \& Pascual 2002, Vargas-Yáñez et al. 2005).

Community structure and dynamics can be affected by cannibalism (Rudolf 2007), and are also key factors in fisheries management decisions, e.g. the nature of recruitment as a function of spawning stock biomass. Actual recruitment estimations for tuna are fisheries dependent since they are based on the composition of the catch of the juvenile fisheries. These estimators are useful as they provide information on the abundance of juvenile tuna, but they have 2 main limitations: (1) they are fisheries dependent, and (2) they lack information on environmental and ecological processes influencing larval survival and therefore recruitment strength. The ecological mechanisms underlying tuna survival shown in our study may be synthesized better if temperature-recruitment and spawning biomass relationships are further developed from the perspective of improving tuna fisheries assessment.

Acknowledgements. We thank the scientific personnel and the crew participating in the TUNIBAL surveys; A. Aparicio, R. Balbín, I. A. Catalán, A. Geffen, M. Peck and J. Ruiz for their valuable comments and help; and 3 anonymous reviewers. National Centers for Environmental Prediction reanalysis radiation data was provided by the Physical Sciences Division, Earth System Research Laboratory, NOAA (www. esrl.noaa.gov/psd/). This study was financed by the project 
BALEARES (CTM 2009-07944 MAR). Cruises and field sampling were financed by the project TUNIBAL (REN 200301176). A.U. was supported by a EUR-OCEANS scholarship and by the University of Bergen/Norwegian Research Council.

\section{LITERATURE CITED}

Aksnes DL, Giske J (1993) A theoretical model of aquatic visual feeding. Ecol Model 67:233-250

Aksnes DL, Utne ACV (1997) A revised model of aquatic visual feeding. Sarsia 82:137-147

> Alemany F, Deudero S, Morales-Nin B, López-Jurado JL, Jansá J, Palmer M, Palomera I (2006) Influence of physical environmental factors on the composition and horizontal distribution of summer larval fish assemblages off Mallorca island (Balearic archipelago, western Mediterranean). J Plankton Res 28:473-487

Alemany F, Quintanilla L, Velez-Belchi P, Garcia A and others (2010) Characterization of the spawning habitat of Atlantic bluefin tuna and related species in the Balearic Sea (western Mediterranean). Prog Oceanogr 86:21-38

Beckley LE, Leis JM (2000) Occurrence of tuna and mackerel larvae (Family: Scombridae) off the east coast of South Africa. Mar Freshw Res 51:777-782

Block BA, Teo SLH, Walli A, Boustany A and others (2005) Electronic tagging and population structure of Atlantic bluefin tuna. Nature 434:1121-1127

Boehlert GW, Mundy BC (1993) Ichthyoplankton assemblages at seamounts and oceanic islands. Bull Mar Sci 53: 336-361

Boyce DG, Tittensor DP, Worm B (2008) Effects of temperature on global patterns of tuna and billfish richness. Mar Ecol Prog Ser 355:267-276

Brooks JL, Dodson SI (1965) Predation, body size and composition of plankton. Science 150:28-35

Catalán IA, Alemany F, Morillas A, Morales-Nin B (2007) Diet of larval albacore Thunnus alalunga (Bonnaterre, 1788) off Mallorca Island (NW Mediterranean). Sci Mar 71:347-354

> Chesney EJ (2008) Foraging behavior of bay anchovy larvae, Anchoa mitchilli. J Exp Mar Biol Ecol 362:117-124

> Claessen D, De Roos AM, Persson L (2000) Dwarfs and giants: cannibalism and competition in size-structured populations. Am Nat 155:219-237

> Davis TLO, Jenkins GP, Young JW (1990) Diel patterns of vertical distribution in larvae of southern bluefin Thunnus maccoyii, and other tuna in the East Indian Ocean. Mar Ecol Prog Ser 59:63-74

Fiksen Ø, MacKenzie BW (2002) Process-based models of feeding and prey selection in larval fish. Mar Ecol Prog Ser 243:151-164

Fiksen Ø, Jørgensen C, Kristiansen T, Vikebø F, Huse G (2007) Linking behavioural ecology and oceanography: how behaviour determines growth, mortality and dispersal. Mar Ecol Prog Ser 347:195-205

Folkvord A (1997) Ontogeny of cannibalism in larval and juvenile fishes with special emphasis on Atlantic cod. In: Chambers RC, Trippel EA (eds) Early life history and recruitment in fish populations. Chapman \& Hall, London, p 251-278

Folkvord A, Øiestad V, Kvenseth PG (1994) Growth patterns in three cohorts of Atlantic cod larvae (Gadus morhua L.) studied in a macrocosm. ICES J Mar Sci 51:325-336

Fraser KPP, Lyndon AR, Houlihan DF (1998) Protein synthesis and growth in juvenile Atlantic halibut, Hippoglossus hippoglossus (L.): application of ${ }^{15} \mathrm{~N}$ stable isotope tracer.
Aquacult Res 29:289-298

Garcia A, Cortes D, Ramirez T, Fehri-Bedoui R and others (2006) First data on growth and nucleid acid and protein content of field-captured mediterranean bluefin (Thunnus thynnus) and albacore (Thunnus alalunga) tuna larvae: a comparative study. Sci Mar 70S2:67-78

Gerritsen J, Strickler JR (1977) Encounter probabilities and community structure in zooplankton: a mathematical model. J Fish Res Board Can 34:73-82

Giguère LA, Côté B, St-Pierre JF (1988) Metabolic rates scale isometrically in larval fishes. Mar Ecol Prog Ser 50:13-19

Graham JB, Dickson KA (2004) Tuna comparative physiology. J Exp Biol 207:4015-4024

Hunter JR (1972) Swimming and feeding behavior of larval anchovy Engraulis mordax. Fish Bull 78:89-101

Hunter JR, Kimbrell CA (1980) Early life history of Pacific mackerel, Scomber japonicus. Fish Bull 78:89-101

Juanes F, Buckel JA, Scharf FS (2002) Feeding ecology of piscivorous fishes. In: Hart PJB, Reynolds JD (eds) The handbook of fish biology and fisheries, Vol 1: Fish biology. Blackwell Scientific Publications, London, p 267-283

Kaji T, Tanaka M, Takashi Y, Oka M, Ishibashi N (1996) Preliminary observations on development of Pacific bluefin tuna Thunnus thynnus (Scombridae) larvae reared in the laboratory, with special reference to the digestive system. Mar Freshw Res 47:261-269

Kaji T, Kodama M, Arai H, Tagawa M, Tanaka M (2002) Precocious development of the digestive system in relation to early appearance of piscivory in striped bonito Sarda orientalis larvae. Fish Sci 68:1212-1218

Kristiansen T, Fiksen Ø, Folkvord A (2007) Modelling feeding, growth, and habitat selection in larval Atlantic cod (Gadus morhua): observations and model predictions in a macrocosm environment. Can J Fish Aquat Sci 64: 136-151

Leis JM, Trnski T, Harmelin-Vivien M, Renon JP, Dufour V, Moudni EMK, Galzin R (1991) High concentrations of tuna larvae (Pisces, Scombridae) in near-reef waters of French Polynesia (Society and Tuamotu Islands). Bull Mar Sci 48: 150-158

> Llopiz JK, Richardson DE, Shiroza A, Smith SL, Cowen RK (2010) Distinctions in the diets and distributions of larval tunas and the important role of appendicularians. Limnol Oceanogr 55:983-996

Lovegrove $\mathrm{T}$ (1966) The determination of the dry weight of plankton and the effect of various factors on the values obtained. In: Barners H (ed) Some contemporary studies in marine science. Allen \& Unwin, London, p 429-467

Margulies D (1997) Development of the visual system and inferred performance capabilities of larval and early juvenile scombrids. Mar Freshw Behav Physiol 30:75-98

> Masuda R, Shoji J, Oayama M, Tanaka M (2002) Chub mackerel larvae fed fish larvae can swim faster than those fed rotifers and Artemia nauplii. Fish Sci 68:320-324

> McGurk MD (1986) Natural mortality of marine pelagic fish eggs and larvae: role of spatial patchiness. Mar Ecol Prog Ser 34:227-242

Medina A, Abascal FJ, Aragón L, Mourente G and others (2007) Influence of sampling gear in assessment of reproductive parameters for bluefin tuna in the western Mediterranean. Mar Ecol Prog Ser 337:221-230

Miller JM (1979) Nearshore abundance of tuna (Pisces, Scombridae) larvae in the Hawaiian Islands. Bull Mar Sci 29: $19-26$

Miyashita S, Hattori N, Sawada Y, Ishibashi Y and others (1999) Ontogenetic change in oxygen consumption of bluefin tuna, Thunnus thynnus. Suisanzoshoku 47:269-275 
Miyashita S, Sawada Y, Okada T, Murata O, Kumai H (2001) Morphological development and growth of laboratoryreared larval and juvenile Thunnus thynnus (Pisces: Scombridae). Fish Bull 99:601-616

Morote E, Olivar MP, Pankhurst PM, Villate F, Uriarte I (2008) Trophic ecology of bullet tuna Auxis rochei larvae and ontogeny of feeding-related organs. Mar Ecol Prog Ser 353:243-254

Nishimura K, Hoshino N (1999) Evolution of cannibalism in the larval stage of pelagic fish. Evol Ecol 13:191-209

Ottera H, Folkvord A (1993) Allometric growth in juvenile cod (Gadus morhua L.) and possible effects on cannibalism. J Fish Biol 43:643-645

Perry JC, Roitberg BD (2005) Games among cannibals: competition to cannibalize and parent-offspring conflict lead to increased sibling cannibalism. J Evol Biol 18:1523-1533

Perry JC, Roitberg BD (2006) Trophic egg laying: hypotheses and tests. Oikos 112:706-714

Persson L, De Roos AM (2006) Size-structured interactions and the dynamics of aquatic systems. Pol $\mathrm{J}$ Ecol 54: 621-632

Polis GA (1981) The evolution and dynamics of intraspecific predation. Annu Rev Ecol Syst 12:225-251

Pope JG, Shepherd JG, Webb J (1994) Successful surf-riding on size spectra: the secret of survival in the sea. Philos Trans R Soc Lond B Biol Sci 343:41-49

Rice JA, Crowder LB, Marschall EA (1997) Predation on juvenile fishes: dynamic interactions between size-structured predators and prey. In: Chambers RC, Trippel EA (eds) Early life history and recruitment in fish populations. Chapman \& Hall, London, p 333-356

Rønnestad I, Kamisaka Y, Conceição LEC, Morais S, Tonheim SK (2007) Digestive physiology of marine fish larvae: hormonal control and processing capacity for proteins, peptides and amino acids. Aquaculture 268:82-97

Rosenthal H, Hempel G (1970) Experimental studies in feeding and food requirements of herring larvae (Clupea harengus L.). In: Steele JH (ed) Marine food chains. University of California Press, Berkeley, CA, p 344-364

Rudolf VHW (2007) Consequences of stage-structured predators: cannibalism, behavioral effects and trophic cascades. Ecology 88:2991-3003

Salat J, Pascual J (2002) The oceanographic and metereological station at l'Estartit (NW Mediterranean). Tracking long-term hydrological change in the Mediterranean Sea. CIESM Workshop Series 16:29-32

Satoh K (2010) Horizontal and vertical distribution of larvae of Pacific bluefin tuna Thunnus orientalis in patches entrained in mesoscale eddies. Mar Ecol Prog Ser 404: $227-240$

Sawada Y, Okada T, Miyashita S, Murata O, Kumai H (2005) Completion of the Pacific bluefin tuna Thunnus orientalis (Temminck et Schlegel) life cycle. Aquacult Res 36: 413-421

Scharf FS, Buckel JA, Juanes F, Conover DO (1998) Predation by juvenile piscivorous bluefish (Pomatomus saltatrix): the influence of prey to predator size ratio and prey type on predator capture success and prey profitability. Can J Fish Aquat Sci 55:1695-1703

Seoka M, Kurata M, Kumai H (2007) Effect of docosahexaenoic acid enrichment in Artemia on growth of Pacific bluefin tuna Thunnus orientalis larvae. Aquaculture 270:193-198

Seoka M, Kurata M, Tamagawa R, Biswas AK and others (2008) Dietary supplementation of salmon roe phospholipid enhances the growth and survival of Pacific blue tuna Thunnus orientalis larvae and juveniles. Aquaculture 275:225-234

- Shoji J, Tanaka M (2001) Strong piscivory of Japanese Spanish mackerel larvae from their first feeding. J Fish Biol 59:1682-1685

Smith C, Reay P (1991) Cannibalism in teleost fish. Rev Fish Biol Fish 1:41-64

Tanaka Y, Satoh $\mathrm{K}$, Yamada $\mathrm{H}$, Takebe $\mathrm{T}$, Nikaido $\mathrm{H}$, Shiozawa S (2008) Assessment of the nutritional status of field-caught larval Pacific bluefin tuna by RNA/DNA ratio based on a starvation experiment of hatchery-reared fish. J Exp Mar Biol Ecol 354:56-64

Uotani I, Saito T, Hiranuma K, Nishikawa Y (1990) Feeding habit of bluefin tuna Thunnus thynnus larvae in the Western North Pacific Ocean. Nippon Suisan Gakk 56:713-717

$>$ Urtizberea A, Fiksen Ø, Folkvord A, Irigoien X (2008) Modelling growth of larval anchovies including diel feeding patterns, temperature and body size. J Plankton Res 30: 1369-1383

> Vargas-Yáñez M, Salat J, Puelles MLF, López-Jurado JL and others (2005) Trends and time variability in the northern continental shelf of the western Mediterranean. J Geophys Res 110:C10019, doi:10.1029/2004JC002799

Wood SN 2006. Generalized additive models: an introduction with R. Chapman \& Hall/CRC, Boca Raton, FL

Young JW, Davis TLO (1990) Feeding ecology of larvae of southern bluefin, albacore and skipjack tunas (Pisces: Scombridae) in the eastern Indian Ocean. Mar Ecol Prog Ser 61:17-29 
Appendix 1. Parameterization of the model

Predator visual perception distance (r): The predators' visual perception distance $(r)$ was modeled as a function of the prey image area $A_{\mathrm{p}}\left(\mathrm{m}^{2}\right)$, the beam attenuation coefficient $(c)$, the prey inherent contrast $(C)$, the visual light sensitivity $E^{\prime}(l)$, the light satiation $\left(K_{\mathrm{e}}\right)$ of the visual system of the predator, and the ambient light $\left(E_{\mathrm{o}}\right)$ (Aksnes \& Giske 1993, Aksnes \& Utne 1997, Fiksen \& MacKenzie 2002) (Table A1). $A_{\mathrm{p}}$ depends on standard length (SL) and body depth (dp) measured as the maximum linear dorso-ventral distance (Scharf et al. 1998) and estimated as (A. P. Torres unpubl.):

$$
d p=0.39 \mathrm{SL}-0.40\left(\mathrm{n}=24 ; \mathrm{R}^{2}=0.83 ; \mathrm{p}<0.001\right)
$$

There are no data on eye sensitivity and light satiation in tuna larvae, so we assumed the same eye sensitivity as for cod larva (Fiksen \& MacKenzie 2002) and light satiation as for gobies Gobiusculus flavescens (Aksnes \& Utne 1997). The light cycle is given by:

$$
E_{\mathrm{o}}=-32.27 \text { time }^{2}+774.87 \text { time }-1996
$$

for a daily irradiance cycle as in the Balearic Sea in summer with daylight between 07:00 and 20:00 h, and $E_{0}=0$ assuming total darkness during the night. The irradiance at the surface $E_{\mathrm{o}}$ (also called ambient light) was obtained from the National Centers for Environmental Prediction Reanalysis Database (NCEP1; www.esrl.noaa.gov/psd/data/gridded/data.ncep. reanalysis.html) and averaged for data between 1 June to 31 August 2005 at $39.05^{\circ} \mathrm{N}, 1.875^{\circ} \mathrm{E}$.

Table A1. Variables and parameters used to estimate the

\begin{tabular}{|c|c|c|}
\hline Symbol & Description & Unit \\
\hline SL & Larval standard length & $\mathrm{mm}$ \\
\hline$r$ & Predator visual distance & $\mathrm{m}$ \\
\hline$A_{\mathrm{p}}$ & Prey image area & $\mathrm{m}^{2}$ \\
\hline$C^{p}$ & Beam coefficient ${ }^{a}$ & $m^{-1}$ \\
\hline$C$ & Prey inherent contrast ${ }^{\mathrm{a}}$ & Dimensionless \\
\hline$E^{\prime}$ & Visual sensitivity & Dimensionless \\
\hline$K_{e}$ & Light satiation & \\
\hline$E_{\mathrm{o}}$ & Ambient light & $\mu \mathrm{mol} \mathrm{m} \mathrm{m}^{-2} \mathrm{~s}^{-1}$ \\
\hline time & Hour of the day & $\mathrm{h}$ \\
\hline$d p$ & $\begin{array}{l}\text { Maximum linear dorso-ventral } \\
\text { distance }\end{array}$ & $\mathrm{mm}$ \\
\hline \multicolumn{3}{|c|}{${ }^{\mathrm{a}}$ Value $=0.3$} \\
\hline
\end{tabular}
predator visual perception distance $(r)$

Editorial responsibility: Edward Durbin, Narragansett, Rhode Island, USA
Submitted: September 14, 2010; Accepted: April 29, 2011 Proofs received from author(s): July 6, 2011 